\title{
RH Mathews and anthropological warfare: on writing the biography of a 'self-contained man'
}

\author{
Martin Thomas
}

\section{Introduction: the biographical lacuna}

It is now almost three decades since AP Elkin published in Oceania a three-part article titled 'RH Mathews: his contribution to Aboriginal studies'. ${ }^{1}$ Recently I have been pursuing my own research into Mathews, gathering material for a book that Elkin, had he found the time, might well have written: a biographical study of the surveyor-turnedanthropologist. To use a term that Mathews once employed for extracting information from informants, I have found it a process of 'long \& patient hammering' ${ }^{2}$ Although Mathews' anthropological career, which lasted from the early 1890 s until his death in 1918, gives him presence in a wealth of documentary records, he remains a difficult quarry for the biographer.

The problems I have encountered in coming to grips with his life history are due in part to his extreme reticence in all matters personal. In the words of his son William, RH Mathews was a 'self-contained man'. ${ }^{3}$ In that regard he substantiates a sage observation on the part of Claude Lévi-Strauss - that a calling to anthropology allows an individual in 'an initial state of detachment' to find advantage when approaching different societies 'since he is already halfway towards them'. In his own society Mathews was probably long inured to a degree of personal and intellectual isolation, though it was undoubtedly exacerbated by his exceedingly hostile relations with other members of the small anthropological fraternity in Federation-era Australia.

Without wanting to pre-empt the narrative that follows, one point must be established from the outset. (To do otherwise would perpetuate the confusion that has so clouded his reputation.) This is to say that Mathews was the victim of some extremely unsavoury treatment at the hands of his contemporaries - treatment which, if exposed

1. Elkin 1975a,b, 1976.

2. Mathews to Bates, 26 June 1904, in 365/970/250-381, papers of Daisy Bates, National Library of Australia, Canberra.

3. William Mathews [attrib.], Biographical and historical notes re Mathews family, National Library of Australia Temp. Accession No. 02/295. 


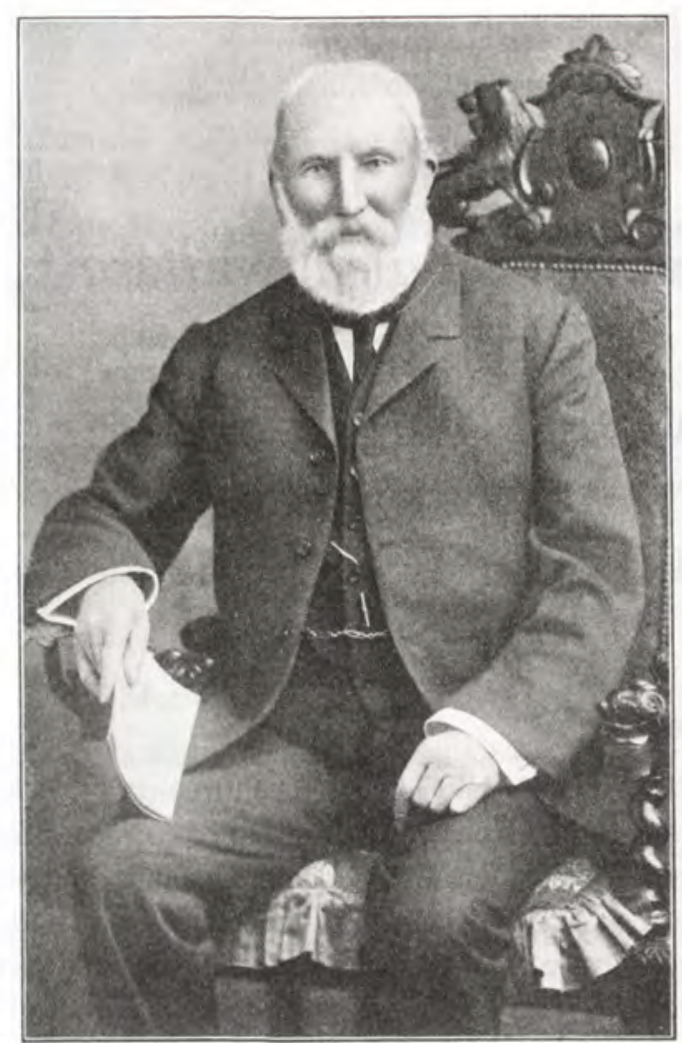

Mr R H. MATHEWS, LS. Assoc Anthrop. Soc. Paris. Parramatta.

Figure 1: Portrait of $\mathrm{RH}$ Mathews dating from around 1909. Courtesy National Library of Australia. today, would be enormously damaging to the perpetrators' reputations. AW Howitt and W Baldwin Spencer, two of his most illustrious contemporaries, formed a compact between themselves that Mathews' numerous publications should never be cited or even acknowledged. This is documented in a letter Spencer wrote to the Queensland ethnologist WE Roth in 1903:

He [Mathews] has a most remarkable faculty of mixing up the [marriage] classes \& is a perfect fraud which once in Sydney I had the pleasure of telling him. Howitt \& myself have agreed to ignore him and I am glad to see that you do the same. ${ }^{5}$

Although Spencer and Howitt each broke their rule on a few occasions, subjecting him to unembarrassed castigation, the usual policy (apparently also shared by Roth) was to treat Mathews as a non-person. Never did they dignify his work by debating his ideas or specifying the grounds for their objections. Consequently, it is difficult for the historian - as it may have been for Mathews himself - to isolate the reasons for their contempt. The feuding was energised by the long tradition of Sydney-Melbourne rivalry and further augmented by an extreme sense of territoriality about who had prior claim to the study of particular tribes. There were also differences in the approach to kinship study, a major concern during this period. Mathews vehemently rejected the 'group marriage theory' ${ }^{\prime 6}$ - a notion to which Howitt and Spencer were famously wedded.

Although the evolutionary anthropology practised by Spencer, Howitt and their colleague Lorimer Fison became severely tarnished with the rise of functionalism, the reputation of the Sydney-based Mathews never entirely recovered from the mauling it suffered at the hands of his Victorian rivals. Subsequent researchers, eager to distance themselves from the 'amateurs' who had pioneered the discipline, did little to evaluate, let alone resuscitate, the work of their forebears. Elkin, who befriended various amateur ethnographers (including EJ Enright, a rare friend of Mathews), was something of an

5. Spencer to Roth, 30 January 1903, in Box 1A/Roth 13, Sir Baldwin Spencer Manuscripts, Pitt Rivers Museum, Oxford.

6. His rejection of group marriage dates from the publication of Mathews 1900: 570 . 
exception in this regard, but he made an unfortunate practice of exploiting these allegiances in his own professional stoushes. This was the case in his first defence of Mathews, published in 1956. Elkin argued that the surveyor-anthropologist's standing had been deliberately eroded by AR Radcliffe-Brown who nonetheless adopted the results of much which Mathews had accomplished' ${ }^{7}$

Elkin's defence of Mathews was quite convincing (and it echoes later criticism that Radcliffe-Brown treated Daisy Bates in similar fashion). ${ }^{8}$ But as an attempt to salvage Mathews' reputation, Elkin's commentary was anything but efficacious. The problem lay in the context of his assault. This near-accusation of plagiarism appeared in nothing less than the obituary he wrote of Radcliffe-Brown, a text that discarded all the conventions of the genre. So scathing was Elkin's attitude towards his one-time mentor that it 'scandalised the profession by its virulence'. ${ }^{9}$ Elkin's later articles on Mathews have proven more enduring, although possibly their many insights were compromised by the author's controversial standing for his social and political views, and for his own involvement in internecine feuding that in some ways resonated with the unfortunate experiences of his subject. The three-part study did little to convince Diane E Barwick, who in 1984 made a damning appraisal of Mathews, criticising his Victorian research for perpetrating a 'sometimes ignorant and sometimes deliberate distortion [that] has so muddled the ethnographic record ...'. Barwick claimed that from 1898 Mathews 'contradicted, ridiculed or ignored' the 'careful ethnographic reports' of Howitt for whom he had an 'almost pathological jealousy'.10

Whatever the merits of Barwick's critique of Mathews' publications on Victoria (which she was certainly well qualified to address), I cannot help but wonder at the personalised tone of her attack and its deliberate one-sidedness. Can one talk legitimately about 'pathological jealousy' on the part of Mathews without considering the 'pathology' of his rival, a man who traded as a disinterested scientist, yet who was willing to disregard as irrelevant the entire corpus of the most prolific commentator on Aboriginal life in south-east Australia - his own area of specialisation? This too might smack of jealousy (to make a generous interpretation). If, at one level, Barwick's attitude seems symptomatic of the fractiousness that continues to poison anthropology as a profession, I suspect that it also reflects a pronounced, indeed gaping, absence in the history of the discipline: the lack, since Elkin, of serious study of the surveyor-anthropologist.

It is an inescapable reality that biographies play an important role in fleshing out the anthropological history. Julie Marcus has demonstrated this convincingly with her vivid portrait of Olive Pink. ${ }^{11}$ In the wake of her book, it becomes very difficult to dismiss Pink as the troublesome maverick or outright nutcase who has often been depicted. Thinking about Mathews' typecasting as a self-aggrandising fraud, it is worth noting that Barwick's partiality was undoubtedly influenced by Come wind, come weather, the biography of Howitt by his descendant, Mary Alice Walker. ${ }^{12}$ Her book is

\footnotetext{
7. Elkin 1956: 250.

8. Needham 1974: chapter 3.

9. Wise 1985: 222.

10. Barwick 1984: 102.

11. Marcus 2001.

12. Walker 1971.
} 
one of several life histories concerning Australia's anthropological pioneers. Baldwin Spencer was the subject of the exhaustive biography by DI Mulvaney and JH Calaby, published in $1985 .{ }^{13}$ Daisy Bates, who stands as something of a national icon - partly for her curiosity value - has, unsurprisingly, also been the subject of several books. Although none of these studies is exactly hagiographic, their influence confirms a broader pattern in historiography. Because of its partiality, its unapologetic concern with the course of a single life, biographical narrative can be easily relegated as an adjunct to the main business of historical inquiry. Yet this apparent marginality belies the profound impact that the literary reconstruction of past lives can have upon even sceptical interpreters. Tigger Wise has written quite a critical book about Elkin, but still it assists the historian in addressing the anthropological history from his point of view. ${ }^{14}$ Although we may not share Elkin's outlook, the very fact that he has been reconstituted in textual form almost obliges us to assume something of his subjectivity as we form our impressions of his influence and milieu. It follows, therefore, that omissions in the biographical record will also influence the overall perception. Certain actors appear bathed in light, while others - often no less significant - continue to lurk in the shadow.

If all this seems a rather artless way of justifying my project, there is a caveat of sorts. Certainly, my intention in this essay is to begin the process of filling a 'gap' in the current literature by expanding on what has hitherto been written about the life and times of RH Mathews. Yet in doing this I have attempted to squarely countenance the problems posed by his 'self-containment'. Rather than pretend that any life story can be systematically reconstituted if the biographer's torch is shone with sufficient skill, the mercurial qualities of Mathews' character have forced me to consider the artificiality of all biographical constructions. By acknowledging this artifice - this cultural specificity - it becomes possible to think in very different ways about Mathews' publications and archival records: the fragments that give him meaning in the present day. Reading the conundrum of RH Mathews is a way of extending his own experiments in what we now call cross-cultural research. We can negotiate the material and intellectual exchanges that occurred during his unique attempt to bring the customs and traditions of Aboriginal Australia to an international readership - a process that also marked his authorial coming-into-being. For all the difficulties he poses as a subject, Mathews' legacy is an extraordinary record of Aboriginal culture, created at a time of great sorrow and despair at the loss of land and traditions. Mathews' self-defined trajectory as an anthropologist was propelled by indefatigable energy and passion, just as it was compromised by hubris, ambition and intrigue. If nothing else, a reading of RH Mathews makes for a compelling story.

\section{Re-evaluating Mathews' significance}

The basic elements of Mathews' life history have been set out in the Elkin articles and also in Isabel McBryde's contribution to the Australian dictionary of biography. ${ }^{15}$ In the following pages I have drawn further information from a biographical sketch in manu-

13. Mulvaney and Calaby 1985.

14. Wise 1985.

15. McBryde 1974: 225-6. 
script form, recently acquired by the National Library of Australia. This important source is attributed to William Mathews (1883-1967), the sixth child of $\mathrm{RH}$, and appears to be based on discussions with his father in his later years. ${ }^{16}$

Robert Hamilton Mathews was born at Narellan, south-west of Sydney, in 1841. He died at Parramatta in 1918. His family were protestants who at the time of his birth had recently emigrated from Northern Ireland. Most of his childhood was spent on a pastoral property at Breadalbane near the town of Goulburn. The education of Mathews and his siblings was entrusted to a private tutor, although sometimes his father, a graduate of Queen's College, Belfast, contributed to their tuition. Aboriginal people (possibly of Gundungurra descent) lived on or near the Mathews property and he once stated that 'black children were among my earliest playmates' ${ }^{17}$ Around 1855 the young Robert met a surveyor called John F Mann who was working along the Great Southern Road. ${ }^{18}$ Intrigued at his activities, the boy devised his own games in imitation. He later related how he made a surveyor's chain from bark and played at measuring the country with an Aboriginal friend. ${ }^{19}$

As a young man $\mathrm{RH}$ Mathews was involved in various rural activities including a droving expedition into Queensland. He had opportunities to meet with and observe Aboriginal people during these years. But his original interest in surveying never diminished and eventually he took formal training in the profession, passing his final exams in 1870. Then followed ten hard years doing government and private surveys in central and western New South Wales. He married Mary Bartlett of Tamworth in 1872 and began a family. They had seven children altogether, one of whom died quite young. Two of the sons became prominent. The eldest, Hamilton B Mathews (18731959), joined his father's profession and eventually became surveyor-general of New South Wales. The third child, Gregory M Mathews (1876-1949), became internationally renowned as an ornithologist, bibliophile and publisher of the 7000 page Birds of Australia (1910-27), a modern work to rival Gould. In a memoir dating from 1942, Gregory explained that through astute management of his surveying practice, RH Mathews had, by the age of forty, amassed 'a competence and could call himself an independent gentleman'. ${ }^{20}$ The family settled in Singleton in 1880 and two years later Robert and Mary travelled the world, leaving their children with a nanny. This was the only time that $\mathrm{RH}$ Mathews ever left Australia. After his return in 1883, he seldom worked full-time as a surveyor. He was a Justice of the Peace which allowed him to preside as a magistrate at local courts. He was also a district coroner and was sufficiently versed in legal practice to publish Handbook to magisterial inquiries in New South Wales (1888) which marked his debut as an author. Mathews was also involved in various business dealings around Sydney, one of which - a failed mining venture - cost him a large sum of money

16. William Mathews [attrib.], Biographical and historical notes re Mathews family, National Library of Australia Temp. Accession No. 02/295.

17. Mathews 1904: 203.

18. The connection is interesting because Mann, like Mathews, was a member of the Royal Society of New South Wales who published ethnological articles (for example see Mann 1885).

19. William Mathews [attrib.], Biographical and historical notes re Mathews family, National Library of Australia Temp. Accession No. 02/295.

20. GM Mathews 1942: 12. 
although he was by no means ruined financially. Because his sons were enrolled at the King's School in Parramatta (then the western edge of Sydney), the family moved there in 1889. Mathews resided at the one house in Hassall Street, Parramatta, until his death.

Anthropological interests developed after the move to Parramatta. His first paper was published by the Royal Society of New South Wales in 1893. From that time he became fully immersed in the study of Aboriginal society. His interests are documented in his 169 anthropological publications. Significant insights into his working methods can also be drawn from the diaries, letters, notebooks, drafts and inchoate scribblings that fill fourteen archive boxes in the National Library of Australia.

Despite its relative abundance, the archival material epitomises the problem that Mathews poses for biographical interpretation. The records are so bereft of self-reflection that they give little indication as to why he embarked on this time-consuming and expensive project. Elkin remarked that ' $[t]$ he surveyor, the ethnographer, made a great and basic contribution, but the philosopher was seldom in evidence'. ${ }^{21}$ Concordant with this observation was a deep reluctance to 'philosophise' about himself. Consequently, the archival record is lacking in inner dialogue, a trait that says much about the scientism of this formative phase in anthropological history, just as it reflects how white masculinity was moulded and constructed during the Victorian and Edwardian periods. Mathews' papers are historically important for what they reveal about his working methods. Frequently they include the names of Indigenous informants which are often lacking in the published articles. But there are very few descriptions of his human interactions and only minimal explication of the quarrels and controversies that won him notoriety. In this regard the Mathews archive is a surplus of bones served up with the barest minimum of flesh. The traces that Mathews left for posterity are reminiscent of a washed-up carapace.

These difficulties might explain why Elkin never developed a full biography. But other aspects of his account are less easily explained. I should preface the following criticisms by emphasising that the value of Elkin's articles is still considerable, for he had an understanding of Mathews that in some respects can never be surpassed. As well as being friendly with Enright, to whom Mathews had been a mentor, Elkin's early work in South Australia led him to settlers with whom Mathews had directly corresponded in his quest for ethnographic data. ${ }^{22}$ This said, there are aspects of Elkin's description of anthropology's emergence that make his account something akin to a mythological project. He drafted biographical sketches of the 'ten persons whom I am regarding as "founders" of social anthropology in Australia': ${ }^{23}$ alongside Mathews he included LE Threlkeld, William Ridley, Lorimer Fison, AW Howitt, George Taplin, EM Curr, John Mathew, WE Roth and W Baldwin Spencer - a list which, though generally sound, is certainly quixotic in its gender-specificity. The omission of Daisy Bates, for all her foibles, is particularly startling. (She and Mathews actually corresponded from 1905 until 1911.)

21. Elkin 1975b: 143.

22. Elkin 1975b: 127.

23. Elkin 1975a: 1. 
In mustering this ensemble of founding fathers Elkin did acknowledge that Howitt and Fison joined ranks with Professor Spencer to form a 'close, or indeed closed, group', ${ }^{24}$ but in so doing he says nothing of their real attitude to Mathews. The latter is eloquently encapsulated in letters Spencer wrote to Howitt. They contain putdowns that are exquisitely venomous. In 1907 Spencer referred to Mathews as 'that miscreant' who put him in the invidious situation of whether to 'admire most his impudence his boldness or his mendacity - they are all of a very high order and seldom combined to so high a degree in one mortal man' ${ }^{25}$ E Morris Miller, who became influential in psychology, penned an eyewitness account of the bodily effect upon Spencer of reading a Mathews article. 'He was convulsed at Mr Mathews' audacity. ${ }^{26}$ Elkin would not have seen these letters, but he knew their essence, for the feuding was evident in sources he consulted. ${ }^{27}$ Mathews' own articles reveal the basic narrative: that hostility between himself and Howitt festered for years until finally the boil erupted in 1907 with an unseemly spat in the letters pages of Nature. ${ }^{28}$ Elkin's ability to overlook this seething antagonism is part of a more general failure to account for the social (or, to put it more aptly, antisocial) context that distinguishes the emergence of Australian anthropology. The failing is exacerbated by Elkin's bubbling enthusiasm for the unpaid devotees who did so much to pioneer the discipline. The impression created is of a golden age in collegial culture, a happy and enlightened fraternity united by scientific interest, the likes of which bore no resemblance to anything Mathews experienced and which Elkin, as I have already suggested, infamously failed to incubate in his own milieu.

One would think that some account of the disagreement between Mathews and the Victorians should grace the anthropological history - for its gossip value if nothing else! But the omission has had serious consequences. I doubt that Barwick could have written off Mathews in the way she did if Elkin had given some account of Spencer and Howitt's actions. Her dismissal is symptomatic of a still lingering suspicion about the value of his research. Kevin Blackburn drew heavily from the Mathews legacy in his 2002 article on 'Aboriginal nations', although he warned the reader that Mathews 'frequently used the work of Howitt and other early Australian anthropologists without acknowledgment' ${ }^{29}$ The sole problem with this accusation is that Blackburn provided not a single shred of evidence to substantiate the claim. (Would he have had the courage to say this about a living writer?) What Blackburn makes evident is just how much mud has stuck to the surveyor from Parramatta. The image of a petulant and untrustworthy researcher has become so enshrined in the anthropological folklore that it can be uncritically regurgitated whenever occasion demands.

24. Elkin 1975a: 18.

25. Spencer to Howitt, 15 August 1907, in MS 9356/Box 1049/7(b), AW Howitt papers, State Library of Victoria, Melbourne.

26. Miller to Howitt, 13 August 1907, in MS 9356/Box 1049/7(a), AW Howitt papers, State Library of Victoria, Melbourne.

27. These include a denunciation of Mathews in Spencer 1904: 380 (note) and the arguments in Howitt 1907 and 1908.

28. See Mathews 1907b; Howitt 1907; Mathews 1907c.

29. Blackburn 2002: 144 . 
Aspersions like Blackburn's reflect a deep discomfort. The frequent lack of primary evidence forces practitioners in a now professionalised field of Aboriginal studies to grapple with the inevitably imperfect deliberations of their amateur antecedents. Mathews, for instance, is sometimes dismissed for his lack of fieldwork: a criticism doubly flawed. Firstly, it overlooks his frequent visits to Aboriginal camps and reserves (documented in extant diaries). Secondly, it upholds the type of live-in fieldwork practised by Malinowski as the inviolable model against which all cross-cultural research should be measured. Not only is it anachronistic to bemoan the fact that the pioneers of Australian anthropology did not go and live as 'natives' (an idea that would have seemed ludicrous to them), but it obscures the unique methods that people like Mathews developed from their own finite resources.

The fact that Mathews made extensive use of correspondents is similarly seen as problematic. These unpaid contributors to the anthropological cause were white settlers in remote locations who spoke to local Aborigines about their beliefs and traditions. The results were written up in letters and sent to Parramatta through the penny post. From a professional perspective it might seem ridiculous that untrained farmers, mission managers or policeman should be hacking away at the ethnographic coalface. But to Mathews this was not an unreasonable proposition. His own background in surveying had given him insights into the primacy of land in Aboriginal culture - even though, ironically, he had contributed as a minor player to Aboriginal displacement through his role in subdividing properties and laying out towns. The legacy of this experience was that Mathews knew the Australian backblocks personally. He had a range of contacts and a degree of authority through his position as coroner and magistrate. He also recognised that areas such as western New South Wales contained heterogenous and sometimes interactive communities. On a station with a large contingent of Aboriginal workers, interpersonal exchange could be the rule rather than the exception. Quotidian relations between settler and employee gave rise to a realm of knowledge which, if properly tapped, could allow a researcher to access traditions that were ancient and endangered.

It should be kept in mind that Mathews inhabited a culture which acknowledged the potential of well placed and observant amateurs to make real contributions to science. Although it was difficult to inspire settlers to assist him, the results were sometimes impressive - as can be seen in some of Mathews' work on northern Australia. His own travels were largely confined to the south-east of the continent, so he depended entirely on a correspondent when he wrote about elements of the Tjingili language in the Northern Territory. ${ }^{30}$ When the linguist N Chadwick appraised the results in 1972, he concluded that the vocabulary 'is truly excellent for its period'. ${ }^{31}$ This was possible because some of Mathews' correspondents were fairly fluent in Aboriginal languages. Although unorthodox in contemporary terms, his attempts to plumb settler understandings of Aboriginal Australia must be seen as a distinct and innovative phenomenon. His persistent inquiries gave rise to a vast discursive record that has, to date, been largely unexplored. The letters he received, many of which survive among the National Library papers, constitute a unique historical resource which, among other

30. Published in Mathews 1900-01: 86-9.

31. Chadwick 1972: 276. 
things, represents an extraordinary survey of white people's attitudes to race and colonisation. Recent collections of Spencer's correspondence, edited by Mulvaney and collaborators, have done a genuine service in revealing the potential of such resources. They expose the interests, the insights and the prejudices of devoted ethnological correspondents along the colonial frontier. ${ }^{32}$ The hundreds of letters in the National Library's RH Mathews papers are equally fascinating. They originate from every Australian colony except Tasmania. As much as they reveal the gulf between cultures, they also provide evidence of interracial intimacy. An isolated woman described how Aboriginal midwives assisted at a premature delivery - how they tied the umbilical cord with 'rabbit fur made into string' ${ }^{33}$ A South Australian correspondent gave detailed description of circumcision and subincision. The information was correct, he assured Mathews, 'as those boys have all been attended to by myself with ointment \&c. to get the wounds healed up quickly' ${ }^{34}$

\section{Message sticks and offprints}

A fascinating example of exchange between Mathews and a correspondent involved a country policeman who proved spectacularly successful as an ethnological researcher. James S Miller, with whom Mathews enjoyed a prolific correspondence, was a constable stationed at various localities in north-western New South Wales including Cobar, Goodooga and Bourke. For more than a decade he collected data and occasional artefacts which he dispatched by mail to Parramatta. For this service he was awarded in two separate articles with the Mathews equivalent of the Holy Grail - public acknowledgment. 'Mr. Miller displayed great patience and industry in dealing with a difficult subject, and it is hoped others will follow his example', was the first blunt statement of thanks, published in 1897.35 Others would buckle under the Mathews regimen, but Miller remained loyal to the point of sycophancy, carrying out often exacting labour that was quite extraneous to his official duties.

While Mathews maintained a flow of letters and offprints of his own articles (or 'pamphlets' as he often called them), Miller reciprocated by collecting information and occasional examples of material culture. Over a four-month period in 1895, at which time he was stationed at the tiny settlement of Goodooga north of Brewarrina, he sent to Mathews a blackfellow's shield, a stone tomahawk and the first of a collection of message sticks. ${ }^{36}$ The latter formed the subject of an article published in 1897. Message sticks, according to Mathews,

are highly interesting as showing an attempt by a primitive and uncultivated people to develop some method of communicating their thoughts to persons at another place by means of symbols. Speaking generally, the stick is given to the messenger to assist him in remembering the heads of the message by connecting

32. Mulvaney et al. 2000, 2001.

33. Gourlay to Mathews, 9 July 1900, in $8006 / 2$ /1, RH Mathews papers, National Library of Australia, Canberra.

34. Walker to Mathews, 6 January 1899 , in $8006 / 2 / 1$, RH Mathews papers, National Library of Australia, Canberra.

35. Mathews 1897c: 292.

36. Documented in correspondence from Miller to Mathews in MS 8006/2/8, RH Mathews papers, National Library of Australia, Canberra. 
them with certain pictures, marks, or notches cut upon it, which are explained to him before he sets out on his journey. The stick also serves as his credentials, being a confirmation or guarantee of the genuineness of the message. ${ }^{37}$

Mathews described the message sticks he had been given, and how their carriers would advance across the country to advise neighbouring communities about corroborees or other events.

The direct exchange between pamphlets and message sticks suggests a certain equivalence between these items. Yet the two categories of object have been treated very differently in ethnographic discourse and display. If looking for a message stick these days, you will most likely find it in a museum cabinet. This is indeed the case with one message stick formerly owned by Mathews which his son Gregory donated to the Australian Museum in 1929. ${ }^{38}$ A message stick, being Aboriginal and being made of wood, is immediately regarded as an artefact. But there is something in the magic that Westerners attach to writing that prevents us from discerning in a book or pamphlet its basic materiality - even though paper is derived from the same substance. So what is the basis for our differing forms of treatment? Is there anything in Mathews' description of a message stick that could not be said of one of his own booklets? It too communicates through the inscription of 'marks' or 'notches' on a surface. It too travels along trade routes. And like the message stick, the ethnographic text provides evidence (too often uncritically accepted) of the 'genuineness of the message'.

To emphasise the materiality of the ethnographic document runs the risk of sounding a platitude. Yet saying it seems necessary because the anthropological enterprise, which deceptively presents itself as the modelling of one culture by another, but which fundamentally concerns the confluence and manipulation of various and typically dissimilar informational flows, is rarely acknowledged for what it is by those who make the most extensive use of the early anthropological legacy.

If we are to get outside the paradigm of old anthropological conflicts and assumptions, we must abandon the conceit, sacred to the early ethnographers, that their documentary productions provided mirror images of Aboriginal culture: that they were essentially mimetic. Although they might give data about particular language groups, communities, sites and traditions - some of it reliable, some less so - the ethnographic legacy will remain stubbornly elusive until such time as its material qualities and the conditions of it production are understood.

By recognising the internal logic of Mathews' ambitious attempt to synthesise direct interview and observation with the accounts of other published writers and those of his numerous correspondents, one can appreciate the scale and scope of his ethnographic practice. Although his collection and dissemination of data were always a little piecemeal, it is possible to chart a rough periodisation in his spheres of interest. The rock art of the greater Sydney region provided initial inspiration. He published extensively on this subject through the 1890 s. Simultaneously, he took great interest in the male initiation ceremonies of eastern Australia, documenting rituals which, in the 1890s, were sometimes being held for the last time. As early as 1897 he could claim,

37. Mathews $1897 \mathrm{c}: 288$

38. Australian Museum, Sydney, accession number E032197. 
probably with only slight exaggeration, to have given 'tolerably comprehensive descriptions of the types of initiation ceremonies practised by ... tribes occupying about three fourths of the total surface of New South Wales, and reaching ... into Queensland'. 39

In the decade from 1900 Mathews' major concern was kinship study. He published scores of articles on tribal divisions and the rules governing marital alignments. During the same period he published articles on 23 different Aboriginal languages, the majority from southeast Australia. (Further linguistic documentation was included as appendices in other publications.) He also documented mythology, or 'folklore' as he usually called it, not all of which was published. Mathews made important contributions to the understanding of material culture, writing about everything from carved trees to cooking methods and ceremonial objects. Unsurprisingly, his productivity declined as old age advanced. In 1909, when he was nudging 70, Mathews began what now seems his anthropological swansong: a series of five articles on the material culture of death and mourning in western New South Wales.

Of course many criticisms can and should be made of Mathews' research and exposition. His work is often frustrating because language, kinship and myth are separated into different categories as though he were oblivious to the interconnectedness of all these phenomena. Yet one could argue that such interpretive work is our responsibility not his. Mathews saw his role principally as a reporter - and there was always too much to report. Exhibiting a bushman's scepticism of all things highfalutin, his work lacks the evolutionary theory, the obsession with hierarchy - both between and within racial groupings - that makes his competitors' writings so challenging today, particularly for Aboriginal readers. Mathews never expressed maudlin sentiments like those of Spencer and Gillen dating from 1899: 'all that can be done is to gather the few remnants of the tribe into some mission station where the path to final extinction may be made as pleasant as possible'. ${ }^{40}$ Nor did he make any utterance remotely comparable to Howitt's repulsive claim that 'you can't make a silk purse out of a "sow's ear" or an industrious, thrifty sober member of society out of the immediate descendant of a long line of savages' ${ }^{41}$ On the whole, Mathews' tone is value-neutral, although sometimes his enthusiasm for his subject seeps through. An initiation ceremony is described as 'a great educational institution for the admission of the youths ... to the privileges, duties, and obligations of manhood' ${ }^{42}$ Customs are deemed 'highly interesting' ${ }^{43}$ The language group of Wiradjuri he considered a 'great nation' ${ }^{44}$ In 1896 he fondly recalled a survey he had made in southern Queensland and time he had spent with Kamilaroi people 'listening to their legends and their songs, and studying their wonderful class system [of regulating marriage] ${ }^{\prime}{ }^{45}$

\footnotetext{
39. Mathews $1897 \mathrm{~b}: 114$.

40. Spencer and Gillen 1968: 18.

41. Cited in Walker 1971: 220.

42. Mathews 1907a: 5.

43. Mathews 1905: 1.

44. Mathews and Everitt 1900: 265.

45. Mathews 1896a: 137.
} 
John Mathew, the ethnologist and Presbyterian minister from Melbourne, with whom Mathews was sometimes confused, once wrote to him: 'I recognise, like yourself that there still remains a good deal of anthropological material, valuable and untouched, in ground supposed to be worked out'. ${ }^{46} \mathrm{It}$ was an astute observation which says much about the enduring relevance of Mathews' ethnography. Even within the Sydney Basin, he found that the residents of La Perouse and the small encampments along the Hawkesbury could give detailed accounts of language and culture. Through many parts of south-east Australia it is a simple and undeniable fact that RH Mathews was the only writer of his period to take any note whatsoever of the local Aboriginal culture.

\section{Mathews in ethnographic action}

William Mathews was a witness to his father in ethnographic action, though he replicated the old man's reticence when it came to writing his personal experiences. Fortuitously, some of the recollections he had shared with family members were recorded onto tape in 1971 by Janet Mathews (1914-1992) who was married to William's nephew (and thus RH's grandson) Frank Mathews. Janet worked for the Australian Institute of Aboriginal Studies as an ethnographic sound recordistt, developing her own reputation for cross-cultural research. During an interview with her husband in which memories of RH Mathews were documented, she explained how William, or Uncle Bill, as they knew him, was sometimes taken to the Aboriginal settlement of La Perouse on Botany Bay where he was left to wait while his father was working.

The children would play around, sometimes for so long they'd get rather tired of it and Uncle Bill at one stage thoughit, oh, he wished the old man would hurry up and go home so he popped along and looked inside and saw old Mrs Timbery who was one of his best Dharawal informants sitting on a box, [and] your grandfather was sitting on a box with his, notebook and his pencil, writing very hard. They were both smoking pipes and Uncle Bill was waved away and they just had to go and wait. ${ }^{47}$

Family memories of an esteemed forebearr are likely to be sanguine. But the traces of an evidently affectionate relationship can alsso be found in the Mathews notebooks which contain pages and pages of linguistic ancd other data attributed to Mrs Timbery at La Perouse.

Janet Mathews' own work, another: considerable feat of cultural documentation, was partially indebted to the example set by her grandfather-in-law - as she explained on the tape cited above. Along the south ' ccast of New South Wales where she worked extensively from the 1960s, RH Mathews" name was still remembered by Howard Timbery and other Dharawal descendants. Herbert Chapman, who was also among her principal informants, testified that RH Mlathews had been known on the coast as "Mirranen' (meaning 'well-liked man') andl had personally gone through the rites of initiation. ${ }^{48}$ Although Frank Mathews rejjected out of hand this tantalising claim, I do not share his certainty. RH did testify thait he 'always received the complete confidence

46. Mathew to Mathews, 4 May 1908, in MS 8006/2/11, RH Mathews papers, National Library of Australia, Canberra.

47. Frank Mathews interview, AIATSIS Archiive Tape 1954.

48. Frank Mathews interview, AIATSIS ArchiiveTape 1954. For discussion of Janet Mathews see Thomas 2003. 
of the chief men, and thus gained admission to their secret meetings' ${ }^{49}$ This was confirmed by WJ Enright who once accompanied Mathews on a visit to an Aboriginal camp near Port Stephens, north of Sydney. Enright told how Mathews was 'at once received by them as one of the initiated' while he 'remained in the camp "with the women and children," as they jocularly expressed it' ${ }^{50}$ Whether the question of Mathews' reported initiation can ever be firmly resolved seems doubtful. But the fact that he said nothing of it does not eliminate the possibility. Had he sincerely gone through this sacred ritual, he would have been bound not to discuss it.

Whether he personally went through the rites, or whether he gained acceptance because he was recognised as an elder and lawman in his own culture, Mathews certainly did become learned in the rituals of male initiation. His descriptions of ceremonies alone would have made a quite substantial book. A few of these events he witnessed personally, but others were already fading into memory. This was the case with the main south coast ceremony Mathews documented, a rite known as the Bunan which, like most initiations, occurred in forest clearings. The bunan described by Mathews occurred near Coolangatta Mountain at the mouth of the Shoalhaven River near Nowra. It had last been held in the 1880s. Not until 1895 did Mathews' 'native guides' carefully lead him around the site, describing the ceremony in considerable detail and pointing out to him the by now 'faint, indistinct forms of animals' which had been sculpted into the soil of this sacred space. ${ }^{51}$

Work such as this, which is still read attentively, opens up a curious aspect of the Mathews conundrum. Although there has been a lack of research into his life and work, there is no absence of material that draws extensively from what he wrote. These uses range from language recovery projects to native title research, from cultural heritage management to local history. As much as they have been spurned, Mathews' writings have provided fuel for other interpreters. Tindale is a major example of this. According to his bibliography, 120 of Mathews' publications were consulted while drafting the boundaries of Aboriginal Australia. ${ }^{52}$ The ramifications have been substantial. Tindale, of course, provided the template from which the boundaries for land councils and kindred institutions were drawn. To understand Mathews and his significance is anything but an academic question. For better or for worse, his collation of data has directly influenced the cultural and political organisation of contemporary Aboriginal Australia.

\section{Conversion and controversy}

The most prolific anthropological writer of his period, RH Mathews left a unique and in some ways an eccentric corpus. In the quarter century from 1893 until his death he published more than 2200 pages of ethnographic observations. Even when allowance is made for the repetition of some data, this remains a daunting statistic. Owing to the great number of papers and their often repetitive nomenclature (sometimes the same titles were used for different articles), the Mathews opus is also a bibliographer's night-

49. Mathews 1904: 203.

50. Enright 1899: 115-16.

51. Mathews $1896 \mathrm{~b}: 330$.

52. Tindale 1974: $371-5$. 
mare. Confusion about the number of Mathews publications has been common. Some scholars have been led astray by John Greenway's habit of listing appendices as individual articles in the Bibliography of the Australian Aborigines. ${ }^{53}$ My own searching (fairly complete at the time of writing) has yielded 169 anthropological publications. Six were small books or pamphlets, some self-financed and all published in Australia. The remaining 163 appeared in periodicals. (Just two of these were co-authored.) ${ }^{54}$

Mathews began his anthropological career by contributing to local forums. But the colonies (and then the Federation) possessed insufficient journals to accommodate his prolific output. He quickly realised that interest in Australian Aborigines was so strong that his writings might attract an international audience. Of the 163 journal articles, 66 were published in Australia and 97 in other countries. Except for a few pieces in Science of Man, a local anthropological magazine, Mathews' Australian articles appeared in the wide-ranging scientific journals of various royal societies. Overseas, he published mainly in the leading anthropological publications of Britain, France, Austria, Germany and the United States (see Appendix). ${ }^{55}$

So how did RH Mathews, a rural surveyor without so much as a university qualification, become an internationally published author with work translated into foreign languages? The answer lies in the intellectual culture of the small 'royal societies' that had sprung up in colonial centres throughout the British empire. By considering Mathews' involvement in the Royal Society of New South Wales, it is possible to get a sense of the ways in which Aboriginal art and tradition were constituted as objects of scientific knowledge. There are also the seeds of Mathews' authorial ambition and a taste of the controversies that dogged his publishing career.

For many years it has been recognised that in his early days as an ethnographer Mathews ran into serious trouble with colleagues in the Royal Society. The year 1894 should have been his annus mirabilis, for it brought to this unknown scholar the imprimatur of serious recognition. In this year he won the Society's bronze medal and the sum of $£ 25$ for a prize essay on 'Rock paintings and carvings in New South Wales'. That something soured what should have been a considerable triumph is indicated by the fact that the Royal Society of New South Wales, which ordinarily published prize essays as a matter of course, never: printed Mathews' entry in its annual Journal and Proceedings. Typically, Mathews himself left only the most inadequate explanation of this puzzling omission. A note in his manuscripts suggests that 'owing to the great length of the paper' it became 'uncertain' whether the Society could ever accommodate it. ${ }^{56}$ There must have been an extensive correspondence concerning this and other Mathews entanglements, but it has not survived in his own papers, raising the question of whether embarrassing documents were deliberately purged. I have been able to reconstruct the chronology only through the records of the learned societies implicated

53. Greenway 1963: 234 41 .

54. Mathews co-published with WJ Enriight in 1895 and MM Everitt in 1900.

55. A number of the European articless wvere published in French or German. A translator is credited in most of the French articles. This is not the case with the German. Even so, it is doubtful that Mathews wrote in ainy language other than English. Drafts (in English) of most of his German publications survive iin the National Library of Australia manuscripts.

56. 'Rock paintings and carvings of the ,Australian Aborigines [draft]', in MS 8006/5/11, RH Mathews papers, National Library of Australia, Canberra. 
in the affair: the Sydney organisation where it started, the Royal Society of Victoria, the Royal Geographical Society of Australasia (Queensland Branch) and the Anthropological Institute in London. That the fallout from his prize essay could be felt as far away as England is a good measure of Mathews' desire for exposure as an author. It is also a symptom of the highly globalised scientific culture into which he had boisterously plunged.

Mathews' ethnological conversion - and I use the term advisedly - had its seed in early 1892. The location was the hamlet of Milbrodale, about twenty kilometres south of Singleton, where Mathews was making a routine survey for a farmer named Benjamin Richards. As William Mathews recounted the Milbrodale experience, his brother Hamilton was assisting their father when someone on the farm told them 'of the existence of a rather striking aboriginal painting of a human figure in a cave in the vicinity ${ }^{\prime}{ }^{57}$ In this way Mathews' attention was drawn to one of the great Aboriginal art sites of eastern Australia, a representation of the creation hero or 'great spirit' known as Baiame (his spelling).

It is not altogether surprising that Mathews, on seeing this huge, painted image, was inspired 'to make an accurate copy of it'. ${ }^{58}$. Few observers would be unaffected by the painting in that sandstone shelter. Baiame is stunningly depicted in red and white ochre. His eyes are large and almost luminous, and his arms are extraordinary. They are greatly exaggerated in proportion to the rest of him, extending laterally from the torso, reaching across the wall of the cave, so as to measure five metres from fingertip to fingertip.

In later years, Mathews would do much to chart Baiame's exploits on Earth, documenting myths, ceremonies, landforms and mythic journeys associated with the great spirit. His interest undoubtedly reflected that of his informants, but it also underscored his own biographical narrative, for the encounter with Baiame really was the fulcrum upon which his life shifted. Having drafted what was actually quite a crude sketch of the figure, Mathews went further. In October the following year he shared his observations in an address to the Royal Society of New South Wales. For 17 years he had been a member of this small though influential scientific organisation, a body inspired by though quite separate from - its august London namesake. But this was the first time he had ever given a paper.

The presentation was published as 'Rock paintings by the Aborigines in caves on Bulgar Creek, near Singleton' in the Royal Society's annual Journal and Proceedings for 1893. Accompanied by drawings and a map of the locality, it concerned both the Baiame site and another nearby cave containing hand stencils. While revealing some residual knowledge of Aboriginal customs, this first ethnological publication is quite prosaic. Mathews states unashamedly that he has confined himself 'as much as possible to descriptions only of these drawings, and ... not attempted to connect them with the myths and superstitions of the Australian aborigines'. With the benefit of hindsight

57. William Mathews [attrib.], Biographical and historical notes re Mathews family, National Library of Australia Temp. Accession No. 02/295.

58. William Mathews [attrib.], Biographical and historical notes re Mathews family, National Library of Australia Temp. Accession No. 02/295. 


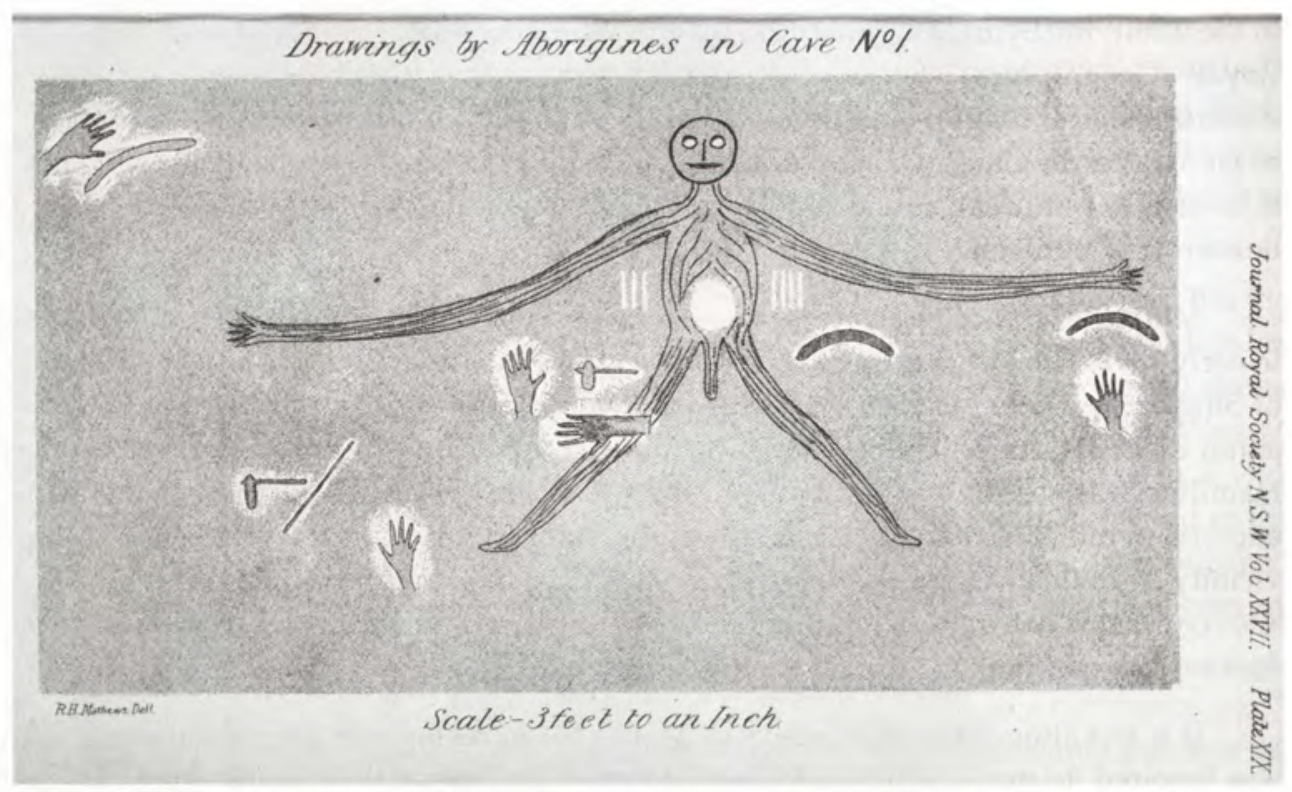

Figure 2: Mathews' documentation of the Baiame cave at Milbrodale in the Hunter Valley, New South Wales. Published by the Royal Society of New South Wales in 1893. Courtesy National Library of Australia

there is a certain humour in his remark that he will leave these more detailed questions 'for those better qualified to follow them than I am, or have more time at their disposal' ${ }^{59}$ As events transpired, he would, for the remainder of his life, have very little time for anything else.

The way in which this isolated documentation of an Aboriginal site became the entrée to a much larger project is explained by William Mathews. After his father had presented his Royal Society paper, he was approached by WD Campbell, also a surveyor, who had been 'collecting material for an essay on that particular phase of the Aborigines' art for the purpose of competing for the bronze medal and prize of twenty five pounds which had been offered by the Royal Society for the best paper on the Aboriginal Rock Carvings and Paintings in New South Wales'. ${ }^{60}$ Until then Mathews had not thought of entering the competition. But the reception of his paper had been encouraging and he eventually resolved to work quickly to prepare an entry by the competition deadline of 1 May 1894.

As Mathews realised, the Hawkesbury sandstone that forms the bedrock of the Sydney Basin provided the material for a distinctive regional style of rock art. In the Sydney region alone, 875 rock shelters containing motifs painted in pigment have been recorded. There are almost as many engravings on exposed rock platforms. ${ }^{61}$ This rich artistic legacy was created by the traditional Dharug-speaking communities who took

59. Mathews 1893: 358 .

60. William Mathews [attrib.], Biographical and historical notes re Mathews family, National Library of Australia Temp. Accession No. 02/295.

61. Attenbrow 2002: 146. 
advantage of the abundant expanses of flat sandstone when they created what were often complex series of pictorial engravings. These carved outlines of people, animals, artefacts and spirit ancestors, some isolated and others presented in dispersed arrangements, represent the most spectacular and distinctive aspect of Sydney's Indigenous art. Europeans from the time of the First Fleet had been moved to comment on, or reproduce in their notebooks, the rock art they observed along the Sydney foreshore. But it was only in the late nineteenth century that men including WD Campbell, who had so warmly encouraged Mathews, and RJ Etheridge Junior, a curator at the Australian Museum and also a Royal Society member, were moved to attempt some systematic documentation. This is the climate in which Mathews was working in late 1893 and the early months of 1894 .

From Mathews' notebooks and later published articles it is possible to get a sense of the increasing fervour with which he went about the task of 'collecting' (by which he meant documenting) rock art. Initially he started slowly, visiting a site at Dural, north of Parramatta, in November 1893. This day trip was squeezed in around a glut of surveying work. Over the Christmas period he went to Rylestone, west of the Blue Mountains. In early 1894 he scoured the Sydney area, documenting sites at Botany Bay where he was directly assisted by Aboriginal inhabitants of La Perouse. ${ }^{62} \mathrm{He}$ found other sites at Howes Valley and more near the Hawkesbury River, north of the city. To ensure impartiality, each entrant to the competition was required to adopt a nom-deplume and it seems to have been a custom in the Royal Society to choose a name in Latin. Waggishly, or perhaps not so waggishly, Mathews styled himself Caesar aut Nullus - 'Caesar or no one'. ${ }^{3}$

The prize essay does not survive intact in the $\mathrm{RH}$ Mathews papers, ${ }^{64}$ but manuscript evidence suggests that it described 50 caves and 70 'rock drawings'. Rough handwritten notes are extant and they run to at least 89 pages. ${ }^{65}$ The sheer comprehensiveness of his entry must have been a significant factor in his winning the prize. Nothing in the Royal Society archives supports Mathews' contention that the essay was deemed so long as to be unprintable. Although it was hefty, a contribution in the order of a hundred handwritten pages was hardly unheard of in the journal. ${ }^{66}$ The totality with which Caesar's triumph metamorphosed into Mathews' embarrassment can be mainly attributed to his unquenchable thirst for publication - the beginning of what Spencer irreverently dismissed in a letter to WE Roth as that interminable series of papers. ${ }^{67}$

62. Mathews 1898b: 425.

63. Rough Minutes: Council Meetings 1892-95, in unnumbered Records, Royal Society of New South Wales, Sydney.

64. An 18-page manuscript headed 'Aboriginal rock carvings and paintings' is annotated 'Read before the Royal Society of N. S. Wales August 1 1894' (in MS 8006/5/11, RH Mathews papers, National Library of Australia, Canberra). This must have been a condensed version of the original, presented on the evening he received the award.

65. 'The Aboriginal rock pictures of Australia [draft]', in MS 8006/5/11, RH Mathews papers, National Library of Australia, Canberra.

66. The proof of this is the Royal Society of New South Wales's publication of Mathews 1904. This, Mathews' longest article (reprinted as a book in 1905), runs to 183 printed pages.

67. Spencer to Roth, 30 January 1903, in Box 1A/Roth 13, Sir Baldwin Spencer Manuscripts, Pitt Rivers Museum, Oxford. 


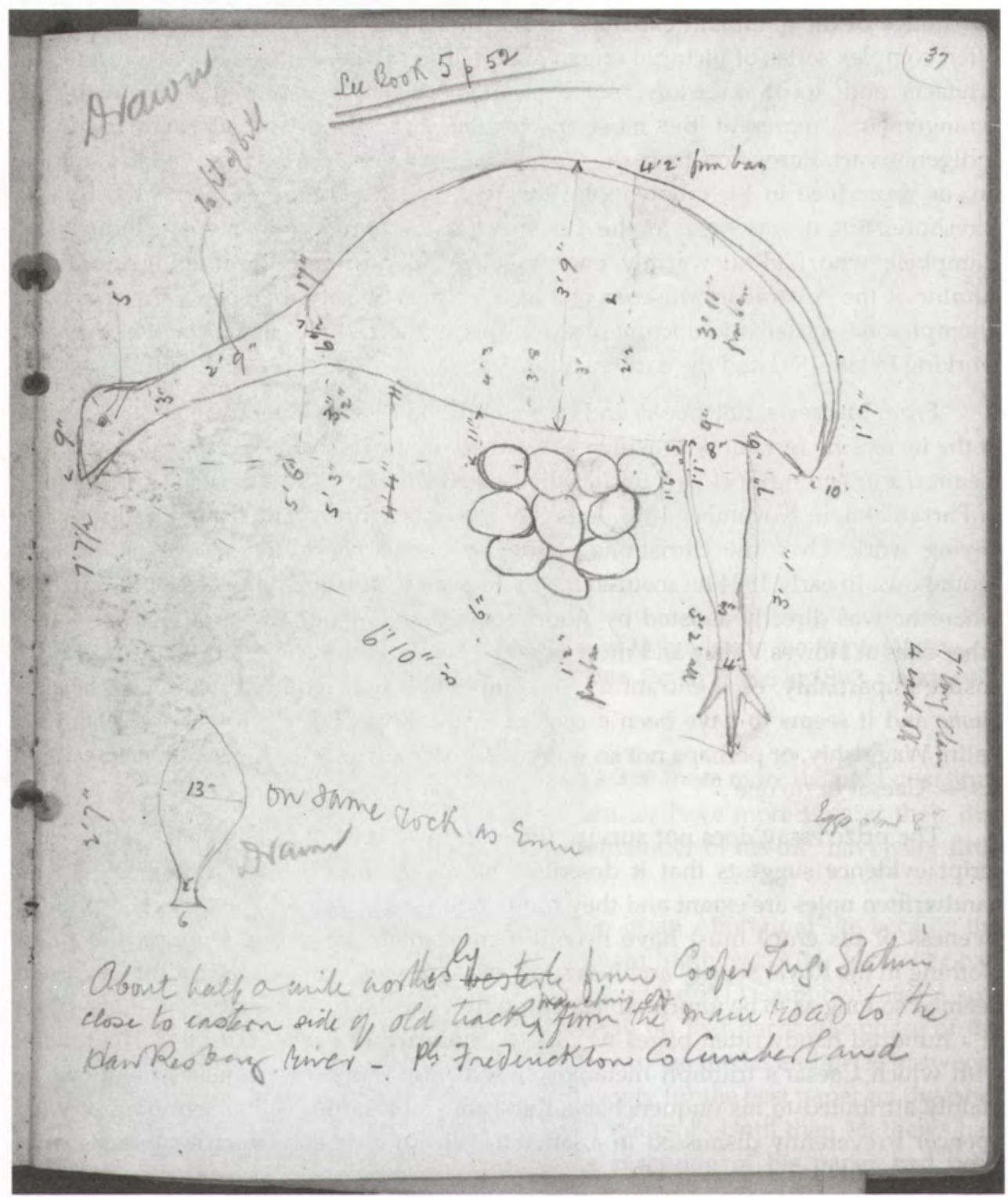

Figure 3: Mathews' documentation of a rock art site near the Hawkesbury River, New South Wales. Field Book No. 1 in NLA MS 8006/3/2. Courtesy National Library of Australia.

The first signs of trouble appeared in late March 1895, some eight months after the award of the prize. The minutes of the Royal Society of New South Wales reveal that the issue of duplication was raised by TW Edgeworth David, the eminent geologist and president of the Society. He informed the council that on 12 July 1894 a rock art paper by Mathews had been read at the Royal Society of Victoria and subsequently published in their journal. 'The text published was practically a condensed form' of the prize essay and the illustrations were 'identical'. David stated that 'he had written to Mr. Mathews asking for an explanation by return of post, but no answer had, as yet, come to hand' ${ }^{68}$ 
The New South Wales Society was unimpressed, but at that stage took the view that the winning essay 'must be published'. In addition to the explanation sought from Mathews, a letter was sent to the Royal Society of Victoria alerting its council to the incident. The inquiries yielded contradictory information: a statement from Mathews that he had forewarned the Victorians of a possible New South Wales publication; a denial from them that he had done any such thing. The Sydney Society resolved that a decision concerning the fate of Mathews' ${ }^{\prime}$ paper would be delayed six months, perhaps hoping that this would place an acceptable interregnum between Mathews' unacceptably similar papers. ${ }^{69}$ The delayed publication in no way affected Mathews' enthusiasm for his new 'pet study' (as he once described his anthropological habit to Daisy Bates). ${ }^{70}$ With the essay prize in the bag, he was now collecting all sorts of ethnographic data, especially on initiation ceremonies. A paper titled 'Aboriginal Bora held at Gundabloui in $1894^{\prime}$ became his second essay published by the Royal Society of New South Wales. ${ }^{71}$

The primary data for this paper had been collected by a police contact in the north-west of New South Wales. Even so, the Gundabloui essay was an impressive piece of research which marked a turn from material culture to ceremonial activity. But to the councillors at the Royal Society, Mathews' new paper became evidence of a disturbing pattern. A few weeks before the society was due to reconsider the publication of the prize essay in 1895 came more unwelcome news. A paper by RH Mathews titled 'The Bora, or Initiation Ceremonies of the Kamilaroi Tribe' had been published in London's Journal of the Anthropological Institute. ${ }^{72}$ The text was almost identical to that of 'Aboriginal Bora held at Gundabloui in $1894{ }^{\prime} .{ }^{73}$ As if things were not bad enough for the anthropological convert, it quickly transpired that Mathews had published another rock art paper, this time in the journal of the Royal Geographical Society of Australasia (Queensland Branch) ${ }^{74}$ Letters were dispatched to Brisbane and London to ascertain whether Mathews had advised these journals that the Royal Society of New South Wales had a prior claim to material they had published. Both replied in the negative. ${ }^{75}$

Although explanations were demanded of Mathews with each new revelation, he seems to have been cheerily oblivious to the storm that was brewing. As the council of the Royal Society of New South Wales sought to manage an imbroglio that now spanned Sydney, Melbourne, Brisbane and London, Mathews was busily submitting new work for their consideration and inquiring regularly about the publication date of his prize essay. This unconcern supports, at least to some degree, an otherwise errone-

68. Council Meetings: Royal Society, NSW 1894-1903, in Records, Royal Society of New South Wales, Sydney. Entry for 27 March 1895.

69. Council Meetings: Royal Society, NSW 1894-1903, in Records, Royal Society of New South Wales, Sydney. Entry for 24 April 1895.

70. Mathews to Bates, 26 June 1904, in 365/970/250-381, papers of Daisy Bates, National Library of Australia, Canberra.

71. Mathews 1894.

72. Mathews 1895.

73. Rough Minutes: Council Meetings 1892-95, in unnumbered Records, Royal Society of New South Wales, Sydney. Entry for 28 August 1895.

74. Mathews 1894-95.

75. Council Minutes, 16 \& 31 October 1895, in Society Records, Royal Geographical Society of Queensland, Brisbane. Entry for 16 October 1895. Council Minutes, in Records, Royal Anthropological Institute, London. Entry for 9 October 1895. 
ous account of the affair in William Mathew's' manuscript. He claims that the charge of duplication was due simply to his father's naive enthusiasm. In the rock art matter this seems possible. My analysis of Mathews' early rock art publications suggests that the amount of duplication was fairly limited. Generally Mathews discussed different examples of rock carvings and paintings in his various papers, but owing to the generic similarity of the artwork itself and the formulaic way in which he described it, they give a strong impression of repetition.

The repetition of that first bora publication represents Mathews' most severe act of duplication during his early period. (Therre were similar, though uncontested occurrences, in the last years of his life.) The two articles, as the Royal Society pointed out, were 'almost identical'. That almost is itself incriminating, for if Mathews had been simply ignorant of scholarly conventions, comsidering himself entitled to publish his research as he pleased in different parts of the world, surely he would have submitted the original article verbatim rather than changing the title, dropping the historical preamble that commences the earlier paper, and making various inconsequential alterations in phraseology. During this periord the demand for original articles was taken very seriously. It was strengthened by the strong competition between various learned societies.

The outward changes Mathews made to his article do not conceal the reality that it was the same bora being described in both publications: an event organised in 1894 by Kamilaroi people on the Moonie River nearr the town of Gundabloui 'about ten miles below where it is crossed by the Queensland boundary'. ${ }^{76}$ That the paper was snapped up by the prestigious Journal of the Anthropeological Institute is a clear indication of the value attached to Mathews' research. Interestingly, the referee who recommended publication was no one less than EB Tyllor, the doyen of British evolutionary anthropology. ${ }^{77}$ The fact that Mathews maanaged to survive this and various other scrapes is an indication that although he was proving a difficult customer, the perceived value of his work outweighed the complications. He was effectively let off with a letter of warning from London. Byy late 1896 the matter of duplication was sufficiently resolved for Mathews to be appointed a Corresponding Member of the Anthropological Institute. This entitled him to complimentary copies of the journal and other privileges enjoyed by fellows.

The allegations of duplication were more vexing for Mathews' colleagues in the Royal Society of New South Wales. They were evidently dissatisfied with the letters he wrote to justify his conduct, ${ }^{78}$ rebuking hirm in 1895 by refusing even to consider his essay on message sticks. ${ }^{79}$ (Eventually it waas accepted by the American Anthropologist.) On the matter of the still-to-be published priize essay, the council decided on 30 October 1895 that 'as Mr Mathews has published so : much of his paper with the publications of

76. Mathews 1894: 98-99.

77. Council Minutes, in Records, Royal Anthropcological Institute, London. Entry for 13 November 1894.

78. Rough Minutes: Council Meetings 1892-95, irn unnumbered Records, Royal Society of New South Wales, Sydney. Entry for 30 October 18895.

79. Rough Minutes: Council Meetings 1892-95, irn unnumbered Records, Royal Society of New South Wales, Sydney. Entry for 27 Novemberr 1895. 
other societies' it was only fitting 'that his paper should be returned' ${ }^{80}$ Mathews protested that they might at least publish part of his essay but his entreaties were useless. The matter disappears from the records with a further letter from Mathews to the executive of the Society which, though bizarre, is a likely indication of the root of the trouble. In his missive Mathews made mention of the list of members that appeared in the opening pages of each year's Journal and Proceedings of the Society. Those who had published papers in the journal were distinguished by the letter ' $P$.' beside their name, followed by a numeral designating the number of publications. The minutes record that Mathews requested that his 'Prize Essay might count as having been published in the Society's Journal; and that P.4 instead of P.3 might be inserted before his name in the new list of members'. Not surprisingly, the councillors were 'unable to accede to his request'. 81

\section{The anthropologist as pamphleteer}

Before 1898, when the rift with the Victorian triumvirate became apparent, Mathews had quoted their work generously and approvingly (a courtesy that neither Spencer, Howitt nor Fison ever paid to him). In an expression of camaraderie that now seems incredible, Mathews in 1897 went so far as to refer to Howitt as 'my friend and fellow worker' ${ }^{82}$ Between Mathews and Spencer relations had also been cordial for a time. The two corresponded briefly ${ }^{83}$ and Spencer, an honorary secretary of the Royal Society of Victoria, is listed as having communicated the two papers Mathews published in the society's journal in $1896 .{ }^{84}$ In his capacity as honorary secretary, Spencer would have known about the charges of duplication when they first emerged, but he did not use them against Mathews at the time.

As Mathews explained to ES Hartland, the major figure in folklore studies with whom he corresponded, 1898 was the year when Spencer decided to do 'all he could to injure me'. The hostility, according to this letter, resulted from Mathews turning his ethnographic attention to the Northern Territory - terrain that Spencer had already claimed for Gillen and himself. ${ }^{85}$ In an act that may have compounded the offence of this 'intrusion' - and which the Victorians undoubtedly discussed - 1898 was also the year in which Mathews (initially with great respect) suggested in print that Howitt had 'evidently been misinformed' when he claimed that descent among certain tribes in southern Queensland was reckoned through the father. ${ }^{86}$

From that date the warfare barely ceased. A full three years after Mathews' death, Spencer lambasted his work. ${ }^{87}$ For years his complaints against Mathews had travelled

80. Rough Minutes: Council Meetings 1892-95, in unnumbered Records, Royal Society of New South Wales, Sydney. Entry for 30 October 1895.

81. Rough Minutes: Council Meetings 1892-95, in unnumbered Records, Royal Society of New South Wales, Sydney. Entry for 30 December 1895.

82. Mathews 1897a: 285.

83. One letter survives in the Mitchell Library: Mathews to Spencer, 24 September 1896, in ML MSS 29/9, Sir Walter Baldwin Spencer papers, Mitchell Library, Sydney.

84. Mathews $1896 \mathrm{a}, \mathrm{c}$.

85. Mathews to Hartland, 12 February 1907, in NLW MS16889, Letters to ES Hartland, National Library of Wales, Aberystwyth.

86. Mathews 1898a: 330.

87. Spencer 1921: 2 . 
the world. Like those dyes used to trace the course of underground currents, the blackening of the surveyor's name can be used to map the powerful network of epistolary relationships maintained by the man, twenty years his junior, who became his nemesis. Outwardly he ignored Mathews, but behind the scenes there was frequent chatter about the 'miscreant' from Parramatta. In two letters written in 1898 Spencer complained about Mathews to the Royal Anthropological Institute of London. One was deemed so 'personal, \& uncalled for' that it was not read at council, ${ }^{88}$ but it proved efficacious since it led to Mathews' corresponding membership of the society being rescinded on a technicality. ${ }^{89}$

Spencer's smear campaign reached the very top of the discipline in 1903 when he complained to JG Frazer, the mighty author of The golden bough, that 'Mr M. pours out so many papers that writers at home [meaning the Mother Country] who cannot know anything of the way in which he gets his information are apt to think that he is reliable'. ${ }^{90}$ Later character assassination must have followeid, for a letter survives from 1908 in which Frazer says to Spencer:

As for that fellow R. H. Matthews [sic], of course I shall not even mention him or any of his multitudinous writings. He wrote to me twice in a tone which showed the character of the man. I did not answer his letters and shall hold no communication with him. ${ }^{91}$

This hostility is evidence of Mathews' unwitting envelopment in a separate anthropology war - the bitter dispute between Frazer and another high profile Briton, Andrew Lang. ${ }^{92}$ Spencer, who was steadfastly aligned with Frazer, had been infuriated when, in 1903, he read Lang's claim that Mathews: was the most lucid and 'well informed writer on the various divisions which regulate the marriages of the Australian tribes'. ${ }^{93}$ While Lang supported Mathews, as did NWW Thomas, who used his work approvingly in Kinship organisations and group marriage in Australia (1906), Mathews never benefited from the powerful overseas patronage enjoyed by Spencer, Howitt and Fison. (Hartland did not enjoy such prestige because he was aligned with folklore study which, unlike anthropology, never became professionalised within the academies.) The efficacy of Spencer's campaign against Mathews is demonstrated by Frazer's four volume Totemism and exogamy (1910), a work that dra'ws extensively from Australian material. ${ }^{94}$ Mathews had published scores of articles on totems and marriage customs. But he rated not a footnote in Frazer's text.

88. Council Minutes, in Records, Royal Anthropological Insttitute, London. Entry for 8 March 1898. Although the author of the letter was not named in the minutes, he was identified as the honorary secretary of the Royal Society of Victoria.

89. Stocking 1995: 343 (note).

90. Spencer to Frazer, 13 June 1903, in PRM Box 5/Frazer 51, Sir Baldwin Spencer Manuscripts, Pitt Rivers Museum, Oxford.

91. Frazer to Spencer, 19 April 1908, in PRM Box 5/Frazer 70, Sir Baldwin Spencer Manuscripts, Pitt Rivers Museum, Oxford.

92. See Stocking 1995, chapter 4.

93. Lang 1903: 38.

94. Consequently, Mathews was not cited by Freud who drew heavily upon Totemism and exogamy in Totem and taboo (1913). Of course Howitt and SSpencer were cited. So was the Australian ethnographer ALP Cameron, a minor figure compared to Mathews. 
Irrespective of the problems he presented as a personality, the treatment meted out to Mathews was scandalous. It makes a complete mockery of the scientific pretensions of his adversaries. Surely it is a most basic precept that a 'scientist' will evaluate any contribution to the discipline on objective principles and not dismiss it because of scuttlebutt transmitted through the old boys' network. My own reading of Mathews' opus, coupled with a knowledge of the bulk of his unpublished papers, confirms the substantial justice of a remark by Ian Langham, the historian of kinship studies, who claimed that although 'many of his papers are repetitive, the amount of original material contained therein is still sufficient to entitle Mathews to a front ranking among the pioneers of Australian anthropology'. ${ }^{95}$

That his isolation resulted in added need for rigour is one of the surprising admissions that Mathews communicated to Hartland. There were positives, he suggested, to the way he had been marginalised.

Ever since 1898 the fact has been thrust upon me that Spencer and Howitt looked upon me as 'the opposition candidate' and never lost a chance of doing me an injury. I was thus kept continually 'on my mettle' and took every precaution double precautions - to keep my statements unassailable. When I found it necessary to amend any of my results I did it immediately, so as not to give my enemies a chance of correcting me. I referred and re-referred the information sent me by old residents of Central Australia back to them for further sifting and inquiry ... I was the 'head and front' of the investigation and my men worked and re-worked under my directions. This has been going on for 13 years (since 1894) as shown by my pamphlets. I had the warning continually before me that any mistake of mine would meet with no mercy. When my men differed from S[pencer] \& G[illen] I sent them copies of what S \& G had said and asked them to try again - to check and re-check. 96

Mathews' claim that the climate of hostility necessitated extra diligence on his part was no doubt accurate. But the effect of this anthropology war was not always positive. Mathews' authorial voice became ever more strident as the years progressed. He denounced the Victorians for minor oversights and developed a tendency to footnote only himself. Without a research culture of respectful criticism, he failed to develop major monographs. Instead he persisted with that 'interminable series of papers'.

Within the closed circle of the triumvirate, the Victorians certainly assisted and promoted each other. Mulvaney has described Spencer's exertions in encouraging the ageing Howitt to synthesise his disparate articles and notes into The Native tribes of south-east Australia (1904) which was published by George Macmillan, a friend of Spencer's from Oxford days. ${ }^{97}$ Mathews, in contrast, had no joy whatsoever when he submitted a manuscript to the same publisher in 1906. He voiced his suspicions to Hartland: 'I think they submitted it to Howitt or Spencer, who it is needless to add would condemn it to make room for their own books' ${ }^{98}$ This could only have added to the

95. Langham 1981: 38.

96. Mathews to Hartland, 12 February 1907, in NLW MS16889, Letters to ES Hartland, National Library of Wales, Aberystwyth.

97. Mulvaney and Calaby 1985: 393-4.

98. Mathews to Hartland, 12 February 1907, in NLW MS16889, Letters to ES Hartland, National Library of Wales, Aberystwyth. 
insult of Howitt's hefty tome, for it contained a travesty of omission greater even than Frazer's. Howitt may have started earlier, kut Mathews had long overtaken him as the most prolific ethnographic commentator or south-east Australia. Imagine his indignation when he discovered that not one of the 819 pages in The Native tribes of south-east Australia so much as mentioned his name. Mathews complained about this and other matters in his 1907 letter to Nature ${ }^{99}$ and finally Howitt took the bait, responding in the following terms:

I learnt from Mr. Mathews's letter that he has sent 'more than one hundred contributions to various scientific societies.' I have only met with two of them, neither of which recommended itself to me by its accuracy. It is therefore difficult to understand how I can have 'ignored' statements of which I am ignorant. ${ }^{100}$

It was a bare-faced lie. Howitt had been receiving the Proceedings of the Royal Society of Victoria and the Journal of the Anthropological Institute through all the years of Mathews' publishing. Mathews referred to this forcefully in his rejoinder. ${ }^{101}$

Even with an awareness of this mistreatment, it would be easy to dismiss Mathews, with his early tendency to duplicate findings, and his petty ambition to have 'P.4' instead of 'P.3' beside his name, as a creature of vanity who published to the point of promiscuity. This might even be the case: initially I thought so when I obtained copies of his correspondence with the editors of the American Anthropologist and the Proceedings of the American Philosophical Society, his principal fora in the United States. Seeking data on his theories or methodology, I was initially bemused to find letter after letter packed with inquiries about the fate of manuscripts and pedantic instructions about the reproduction of graphics. There were also his endless requests for offprints of articles - the 'separates' or 'pamphlets' as he called them. It is a subject that recurs throughout this correspondence. Typical is this letter to the American Philosophical Society written in 1897:

As regards separates, the Anthropological Society at Washington always supply me with 50 reprints of every paper they publish, which are sent through the International Exchange of the Smithsonian Institution. In addition to this they send me a free copy of the monthly or quarterly part of the journal in which my paper appears. ${ }^{102}$

He also raised the subject with Daisy Bates in a letter that has the flavour of a pep talk.

Did the Geographical Society in Melbourne send you any 'separate copies' of your contribution? You are entitled to either 25 or 50 , whichever number is sanctioned by their rules. 103

This preoccupation with the fine detail of printing, the all-important acquisition of separates, seems symptomatic of a man who practised in a methodological void. But his concerns acquire a logic of their own if we remain sensitive to the paradigm in which he

\footnotetext{
99. Mathews 1907b.

100. Howitt 1907: 81.

101. Mathews $1907 \mathrm{c}: 81$.

102. Mathews to Harrison Allen, undated [18971, Records of the American Philosophical Society, Philadelphia.

103. Mathews to Bates, 17 September 1906, in 365/970/250-381, papers of Daisy Bates, National Library of Australia, Canberra.
} 
worked. Mathews the amanuensis can then be identified as Mathews the maker, and his preoccupation with printing and pamphlets will be seen not as a sign of methodological poverty but as an instance of his method in action. Once this is recognised he will be known as the artisan who drafted manuscripts with his pen and paper then supervised their mechanical transformation into a bundle of pamphlets. From this perspective the ethnographic enterprise assumes a unique guise. Although Mathews seldom gained money from his activity (just a few shillings here and there by selling pamphlets), his function was to oversee an economy of his own creation, a system that involved collection, production, transformation, exchange and return. Tempting as it is to look at the notation in his field books and seek similitude between it and the culture he was writing about, the interpretation will be suspect unless we acknowledge a more cardinal reality: that the page of writing is the sign not of imitation but of transformation. The reality is that the ethnographer's labour is a form of production; that it turns out objects as tangible as the output of any artisan's workshop. That the final stage in the process - the dispatch of a published offprint to the place from whence it came could be a generative moment, the beginning of a whole new cycle, is clearly articulated in another letter to the American Philosophical Society in which he justified his constant anxiety about reprints.

As this article will only occupy a little over a page of your journal, I beg to submit that as soon as the 'separates' are struck off, that half of them be sent to me by the direct mail instead of through the 'International Exchange'. I am making this suggestion because the separates will be very light, - and I am particularly anxious to get the 'reprints' soon so that I can distribute them among the white residents of the Northern Territory in the hope of inducing them to collect similar information respecting other tribes. ${ }^{104}$

To estimate that Mathews received an average of 50 offprints of everything he published is probably conservative. Although, as he pointed out to Bates, some societies supplied only 25 copies, others were prepared, on this matter, to indulge the authors who received not a penny for their work. In 1898 Mathews acknowledged receipt from the American Philosophical Society of '100 copies of my paper on Australian Divisions, for which I thank you very much' ${ }^{105}$ Other papers, like his substantial 'Ethnological notes on the Aboriginal tribes of New South Wales and Victoria' (1904) he had reprinted as a book, in a larger edition, at his own expense. ${ }^{106}$ But even if his 170 ethnological articles (to use a round figure) are multiplied by the modest estimate of 50 reprints the Mathews opus would have yielded a stockpile of 8500 items. When, in the 1960s, Mathews' grandson Frank began to count the residue (which he had inherited), he found 3000 'booklets'. If that number remained after his death, Mathews must have distributed thousands in the course of his life.

'Pamphlets duly read for which many thanks', wrote a correspondent from Port Lincoln, South Australia in $1899 .{ }^{107}$ The line is repeated with countless variations throughout the Mathews correspondence. Who didn't receive his pamphlets during that

104. Mathews to J Minnis Hayes, 24 February 1898. Records of the American Philosophical Society, Philadelphia. Mathews' emphasis.

105. Mathews to Secretary, 31 July 1898. Records of the American Philosophical Society, Philadelphia.

106. Mathews 1905. 
quarter-century he devoted to anthropology? He posted them to new journals when offering his services as a writer. He sent swathes of them to the public libraries in Melbourne and Sydney, taking pains to ensure they were individually catalogued. Missionaries, postmasters, telegraph operators, policemen and any number of farmers in remote or not-so-remote parts of Australia were bombarded with letters and offprints. Sending a pamphlet or two was a way of creating a sense of reciprocal obligation when he 'cold-called' denizens of rural Australia, many of whom were amused rather than inspired by his suggestion that precious leisure hours might be devoted to collecting information about 'natives'.

ES Hartland and WHR Rivers certainly received offprints. He probably sent some to Durkheim, for Mathews' long essay from 1904, published in the Journal and Proceedings of the Royal Society of New South Wales, was cited several times in The elementary forms of the religious life (1915). Durkheim could have even read the article without Mathews' agency, for strange as it may seem, the New South Wales journal was in no way inaccessible to a scholar resident in Paris. If it seems curious that a semi-retired surveyor from Parramatta could manage, with apparent ease, to locate and correspond with learned bodies around the world, the key lies in the list of 'Exchanges and Presentations' printed in the back of the Royal Society's annual. In the year 1895, for example, the Royal Society of New South Wales exchanged publications with 400 institutes, libraries and learned bodies around the globe. Mathews could read any of their publications in the Royal Society library while a reader in Paris, if searching for the Society's Journal and Proceedings, could find it at 39 institutions or libraries in that city alone. ${ }^{108}$ Mathews' cycling of data from his base in Parramatta was but a tiny cog in the great machinery for the distribution of knowledge. With its circular flow between centre and periphery, it was a sign of modernity's grip, hardening on the world.

\section{Coda: a glimpse from the margin}

For three decades after his death, what survived of Mathews' personal library and papers remained in family hands. Then, in the 1950s, Hamilton Mathews allowed Elkin to borrow a trunk full of material - manuscript items and key books - which had been stored in Wollongong. ${ }^{109}$ This loan lasted for a quarter of a century and only after something of a tussle did the Mathews family secure the return of most manuscript items. Eventually they were donated to the National Library of Australia. The borrowed books, however, followed a diffe=ent path. They remained in Elkin's possession until 1974 when he gave them to the Rare Books collection of Sydney University's Fisher Library. ${ }^{110}$ Among the 27 volumes once owned by Mathews are presentation copies from foreign luminaries including Arnold van Gennep, EA Crawley and Andrew Lang. There are also major publications by Mathews' Australian enemies con-

107. Higgins to Mathews, 19 September 1899, in 8006/2/1, RH Mathews papers, National Library of Australia, Canberra.

108. 'Exchanges and Presentations', Joumall ard Proceedings of the Royal Society of New South Wales (1895) 28: 601-10.

109. Elkin 1975b: 127.

110. Certificate of donation and related matterial in AP Elkin papers, University of Sydney Archives: 130/9/130. Elkin's request tha: the books be known as the 'Mathews Collection' was never granted. Fisher Library has; catalogued these items as part of the Elkin Collection. 
taining marginal annotations which display a candour never exhibited in his diaries. Knowing Mathews once declared that if Howitt and Fison had never been born, it could not have made an atom of difference to my work', 111 there is both pleasure and fascination in perusing his copy of Howitt's The native tribes of south-east Australia (1904), the book that snubbed him so comprehensively. The comments written in the margin include: 'No, no!', 'Bunkum', 'Rot', 'Nonsense', 'Bosh', 'Not so!' and, very occasionally, 'Correct'.

While shedding some light on the dispute between the anthropologists, this volume also provides insight into the way Mathews was perceived in eastern Victoria and the culturally connected coastal communities in southern New South Wales where he was better known. As a point of principle, it seems, Mathews' spelling of Indigenous words differed from Howitt's. But he could have only been referring to the same thing when he annotated a page on which Howitt described those persons who were known by the Kurnai of Gippsland as the Birraark. A pencilled note states: 'Birrarak is the name given to me by the natives'. ${ }^{112}$

The lack of reflexivity in Mathews' records is such that I am reliant on his archenemy's description to convey an understanding of what this name might have meant to the people who bestowed it. Howitt claimed that the Birraark:

combined the functions of the seer, the spirit-medium, and the bard, for he foretold future events, he brought the ghosts to the camp of his people at night, and he composed the songs and dances which enlivened their social meetings. He was a harmless being, who devoted himself to performances which very strikingly resembled those of the civilised 'mediums.' A man was supposed to become a Birraark by being initiated by Mrarts or ghosts, when they met him hunting in the bush; but, that they might have power over him, he must at the time be wearing a Gumbart, that is, one of those bone pegs which the Australian aborigine wears thrust through the septum of his nose. By this they held him and conveyed him through the clouds. 113

From Howitt's description it is clear that Birraarks were highly esteemed and widely known in the broad community. He names eight who were living in Gippsland when whites arrived in 1842, although none had survived by the time he started his ethnographic research in the 1870s. Several individual Birraarks were remembered by Howitt's informants who related numerous observations, all of which enliven an understanding of how Mathews' documentary project might have been construed in Aboriginal terms. As a medium between the living and the dead, a Birraark could travel from one realm to the other at will. He conveyed messages and information about the movements of friends or enemies who had died and he could also bring material benefits, the makings of a feast, as happened, for example, when 'the Mrarts informed them of a whale stranded on the shore'. Not only was the Birraark a leader of ceremonial activities during large inter-communal gatherings, but through his mediation with ghosts he brought songs and dances into the world of the living. ${ }^{114}$ Here is

111. Mathews 1904-05: 74 .

112. Howitt 1904: 391. The annotated copy is located at Elkin Collection 262, Rare Books, University of Sydney Fisher Library.

113. Howitt 1904: 389 .

114. Howitt 1904: 390-3. 
rare and compelling evidence of how Mathews was regarded in an Aboriginal community. As a person who moved between worlds he could facilitate the transmission of understandings. In that intermediary capacity he evidently encouraged a two-way traffic in ways of speaking, singing and moving.

With this suggestive image, the Mathews story can be closed (at least for now). As a biographical subject he is heavily obscured, as if by fumes. It is a mixed cloud that enshrouds him. The still-lingering gun-smoke from the anthropological warfare is infused with that of the screen he put about himself to ensure his self-containment. With the passage of time, the sense of Mathews communicated in the journal articles is suggestive of a fragile visage. The authorial voice, a projected version of own likeness, has become his death mask. In that respect it recalls - and arguably embodies - the profound irony that underlies his ethnographic enterprise. In some ways Mathews acted as though he was an intermediary between the living and the dead. His Herculean feat of documentation was predicated on the impending disappearance of the people he described. As he once said to an American editor, Now is the time to locate the different nations, while the blacks are still alive, and not in a few hundred years after they are all dead, as is done with most races' ${ }^{115}$ Like many things human, Mathews' survey of Aboriginal humanity is full of contradictions. The death mask becomes the thing with which we grapple when interpreting his life, while descendants of the very people whose anticipated demise stimulated his research can now be counted as attentive readers.

\section{Acknowledgements}

An honorary Harold White Fellowship at the National Library of Australia in 2002 allowed unparalleled access to RH Mathews' writings and papers. Sarah Walpole generously provided archival records from the Royal Anthropological Institute in London. Thanks also to Kate Khan, John Mulvaney and Naomi Parry for sharing material from their own research.

115. Mathews to J Minnis Hayes, in Records, American Philosophical Society, Philadelphia. 


\section{Appendix: Number of publications by RH Mathews, in periodicals by country (based on a survey of 163 journal articles)}

\section{Australia}

Journal and Proceedings of the Royal Society of New South Wales

Proceedings and Transactions of the Queensland Branch of the Royal Geographical

Society of Australasia (renamed in 1900 Queensland Geographical Journal)

Proceedings of the Royal Society of Queensland

Proceedings of the Royal Society of Victoria

Report of the Australasian Association for the Advancement of Science

Science of Man

USA

American Anthropologist

American Antiquarian

Proceedings of the American Philosophical Society

Science

Great Britain

Folk-Lore

Journal of the Anthropological Institute

Journal of the Transactions of the Victoria Institute

Man

Nature

\section{France}

Bulletins et Mémoires de la Société d'Anthropologie de Paris

Revue d'Ethnographie et de Sociologie

\section{Austria}

Mitteilungen der Anthropologischen Gesellschaft

\section{Germany}

Zeitschrift für Ethnologie

Total

\section{References}

\section{Primary sources}

AW Howitt papers, State Library of Victoria, Melbourne.

Daisy Bates papers, National Library of Australia, Canberra.

Interview with Frank Mathews recorded by Janet Mathews on 8-11 January 1971, Archive Tape 1954, Australian Institute of Aboriginal and Torres Strait Islander Studies.

Letters to ES Hartland, National Library of Wales, Aberystwyth.

Peter Adolphus Elkin papers, University of Sydney Archives.

RH Mathews papers, National Library of Australia, Canberra.

Records of the American Philosophical Society, Philadelphia. 
Records of the Royal Anthropological Institute, London.

Records of the Royal Geographical Society of Queensland, Brisbane.

Records of the Royal Society of New South Wales, Sydney.

Sir Baldwin Spencer manuscripts, Pitt Rivers Museum, Oxford.

Sir Walter Baldwin Spencer papers, Mitchell Library, Sydney.

\section{Secondary sources}

Attenbrow, V 2002, Sydney's Aboriginal past, University of New South Wales Press, Sydney.

Barwick, DE 1984, 'Mapping the past: an atlas of Victoria clans 1835-1904 Part 1', Aboriginal History 8(1-2): 100-31.

Blackburn, K 2002, 'Mapping Aboriginal nations: the "nation" concept of late nineteenth century anthropologists in Australia', Aboriginal History 26: 131-58.

Chadwick, N 1972, 'Mathews' Chingalee vocabularyr: appraisal and comments', Oceania 42(4): 276-82.

Elkin, AP 1956, 'A. R. Radcliffe-Brown, 1880-1955', Oceania 26(4): 239-51.

- 1975a, 'R. H. Mathews: his contribution to Aboriginal Studies: Part I', Oceania 46(1): 1-24.

-1975b, 'R. H. Mathews: his contribution to Aboriginal Studies: Part II', Oceania 46(2): 126-52.

- 1976, 'R. H. Mathews: his contribution to Aborïginal Studies: Part III', Oceania 46(3): 206-34.

Enright, WJ 1899, 'The initiation ceremonies of the Aborigines of Port Stephens, N. S. Wales', Journal and Proceedings of the Royal Sociesty of New South Wales 33: 115-16.

Greenway, J 1963, Bibliography of the Australian Aborigines and the native peoples of Torres Strait to 1959, Angus and Robertson, Sydney.

Howitt, AW 1904, The native tribes of south-east Australia, Macmillan, London.

— 1907, 'Literature relating to Australian Aborigiines [Letter to the editor]', Nature 77(1987): 80-81.

- 1908, 'A message to anthropologists', Revue des; Études Ethnographiques et Sociologiques 1: 481-2.

Lang, A 1903, Social origins, Longmans, Green, and (Co, London.

Langham, I 1981, The building of British social anthropology: W. H. R. Rivers and his Cambridge disciples in the development of kinship studies, D Reidel, Dordrecht.

Lévi-Strauss, C 1992 [1955], Tristes tropiques, transl. JJohn and Doreen Weightman, Penguin, Harmondsworth.

Mann, John F 1885, 'Notes on the Aborigines of Ausitralia', Proceedings of the Geographical Society of Australasia, New South Wales and Victorian Branches 1: 27-63.

Marcus, J 2001, The indomitable Miss Pink: a life in antthropology, University of New South Wales Press, Sydney.

Mathews, GM 1942, Birds and books: the story of the Nathews ornithological library, Verity Hewett Bookshop, Canberra.

Mathews, RH 1893, 'Rock paintings by the Aborigimes in caves on Bulgar Creek, near Singleton', Journal and Proceedings of the Royal Society of New South Wales 27: 353-8. 
- 1894, 'Aboriginal Bora held at Gundabloui in 1894', Journal and Proceedings of the Royal Society of New South Wales 28: 98-129.

-1894-95, 'Aboriginal rock pictures of Australia', Proceedings and Transactions of the Queensland Branch of the Royal Geographical Society of Australasia 10: 46-70.

-1895, 'The Bora, or initiation ceremonies of the Kamilaroi Tribe', Journal of the Anthropological Institute 24: 411-27.

- 1896a, 'The Bora of the Kamilaroi Tribes', Proceedings of the Royal Society of Victoria 9 (New Series): 137-73.

1896b, 'The Bunan ceremony of New South Wales', American Anthropologist 9: 32744.

- 1896c, 'The Burbung of the New England tribes, New South Wales', Proceedings of the Royal Society of Victoria 9 (New Series): 120-36.

- 1897a, 'The Burbung of the Wiradthuri Tribes (Part II)', Journal of the Anthropological Institute 26: 272-85.

- 1897b, 'The Burbung, or initiation ceremonies of the Murrumbidgee Tribes', Journal and Proceedings of the Royal Society of New South Wales 31: 111-53.

- 1897c, 'Message sticks used by the Aborigines of Australia', American Anthropologist 10: 288-97.

- 1898a, 'Divisions of Queensland Aborigines', Proceedings of the American Philosophical Society 37: 327-36.

— 1898b, 'Gravures et peintures sur rochers par les Aborigènes d'Australie', Bulletins et Mémoires de la Société d'Anthropologie de Paris 9 (4th Series): 425-32.

- 1900, 'The origin, organization and ceremonies of the Australian Aborigines', Proceedings of the American Philosophical Society 39: 556-78.

- 1900-01, 'Ethnological notes on the Aboriginal tribes of the Northern Territory', Queensland Geographical Journal 16: 69-90.

-.-1904, 'Ethnological notes on the Aboriginal tribes of New South Wales and Victoria', Journal and Proceedings of the Royal Society of New South Wales 38: 203-381.

- 1904-05, 'Ethnological notes on the Aboriginal tribes of Queensland', Queensland Geographical Journal 20: 49-75.

- 1905, Ethnological notes on the Aboriginal tribes of New South Wales and Victoria, FW White General Printer, Sydney.

- 1907a, Notes on the Aborigines of New South Wales, Government Printer of New South Wales, Sydney.

- 1907b, 'Ethnological notes on the Aboriginal tribes of New South Wales and Victoria [Letter to the Editor]', Nature 76 (1958): 31-2.

- $1907 \mathrm{c}$, 'Literature relating to Australian Aborigines [Letter to the Editor]', Nature 77 (1987): 81.

Mathews, RH and MM Everitt 1900, 'The organisation, language and initiation ceremonies of the Aborigines of the south-east coast of N. S. Wales', Journal and Proceedings of the Royal Society of New South Wales 34: 262-81.

McBryde, I 1974, 'RH Mathews' in Australian dictionary of biography, vol V, B Nairn, G Serle and R Ward (eds) Melbourne University Press, Melbourne: 225-6. 
Mulvaney, DJ and JH Calaby 1985, 'So much that is new': Baldwin Spencer, 1860-1929: a biography, Melbourne University Press, Carlton.

Mulvaney, J, A Petch and H Morphy 2000, From the frontier: outback letters to Baldwin Spencer, Allen \& Unwin, St Leonards, NSW.

-_ (eds) 2001 [1997], My dear Spencer: the letters of F. J. Gillen to Baldwin Spencer, Hyland House, Melbourne.

Needham, R 1974, Remarks and inventions: sceptical essays about kinship, Tavistock Publications, London.

Spencer, B 1904, 'Totemism in Australia', Report of the Australasian Association for the Advancement of Science 10: 376-423.

Spencer, Sir B 1921, 'Blood and shade divisions of Australian tribes', Proceedings of the Royal Society of Victoria 34(1): 1-6.

Spencer, WB and FJ Gillen 1968 [1899], The native tribes of central Australia, Dover, New York.

Stocking Jr, GW 1995, After Tylor: British social anthropology 1888-1951, University of Wisconsin Press, Madison.

Thomas, M 2003, "'To you Mrs Mathews"': the cross-cultural recording of Janet Mathews 1914-1992', Australiasian Sound Archive, 29: 46-59.

Tindale, NB 1974, Aboriginal tribes of Australia: their terrain, environmental controls, distribution, limits and proper names, Australian National University Press, Canberra.

Walker, MH 1971, Come wind, come weather: a biography of Alfred Howitt, Melbourne University Press, Carlton.

Wise, T 1985, The self-made anthropologist: a life of A. P. Elkin, George Allen \& Unwin, Sydney. 